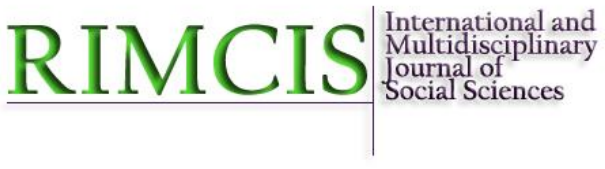

Hipatia Press

Instructions for authors, subscriptions and further details:

http://rimcis.hipatiapress.com

\section{Natural Resource Conflicts as a Struggle for Space: The Case of Mining in Tanzania}

Japhace Poncian ${ }^{1}$, Henry Michel Kigodi ${ }^{2}$

1) Mkwawa University College of Education, Tanzania \& University of Newcastle, Australia

2) Mwalimu Nyerere Memorial University, Tanzania

Date of publication: November $30^{\text {th }}, 2015$

Edition period: November 2015 - March 2016

To cite this article: Poncian, J. \& Kigodi, H.M. (2015). Natural Resource Conflicts as a Struggle for Space: The Case of Mining in Tanzania. International and Multidisciplinary Journal of Social Sciences, 4(3), 271-292. doi: $10.17583 /$ rimcis.2015.1773

To link this article: http://doi.org/10.17583/rimcis.2015.1773

The terms and conditions of use are related to the Open Journal System and to Creative Commons Attribution License (CC-BY). 


\section{Natural Resource Conflicts as a Struggle for Space: The Case of Mining in Tanzania}

Japhace Poncian

Mkwawa University College of

Education \& University of Newcastle
Henry Michael Kigodi

Mwalimu Nyerere Memorial

University

\section{Abstract}

Natural resource extraction in Africa has been characterised by conflicts between large scale and small scale miners on the one hand and large scale miners and the communities on the other. In some countries such as Sudan, Democratic Republic of Congo, Angola, Mozambique, Sierra Leone and Liberia, natural resources have bred political instability and civil wars. A great deal of academic discourse on resource conflicts in Africa focuses on greed, corruption, political struggles for state capture and control over resources, economic liberalisation policies for attracting foreign investors and creating conducive climate for them to invest their capital in natural resource extraction, and foreign forces. While recognising the significance of the above approaches in explaining resource conflicts in Africa, this paper aims at explaining resource conflicts as a struggle for space between the communities, artisanal and small scale miners and large scale foreign mining corporations. Using secondary sources, we argue that some natural resource extraction conflicts in Africa can well be understood if we approach them as a struggle for space. This however, does not mean that current approaches are rendered useless. It rather compliments current approaches.

Keywords: mining, conflicts, space, Tanzania, Africa 


\section{Conflictos por los Recursos Naturales como una Lucha por el Espacio: El Caso de la Minería en Tanzania}

Japhace Poncian

Mkwawa University College of

Education \& University of Newcastle
Henry Michael Kigodi

Mwalimu Nyerere Memorial

Academy

\section{Resumen}

La extracción de recursos naturales en África se ha caracterizado por los conflictos entre mineros a gran escala y pequeña escala, por un lado y los mineros de gran escala y de las comunidades, por la otra. En algunos países como Sudán, República Democrática del Congo, Angola, Mozambique, Sierra Leona y Liberia, los recursos naturales han engendrado inestabilidad política y guerras civiles. Una gran parte del discurso académico sobre conflictos de recursos en África se centra en la codicia, la corrupción, las luchas políticas para la captura del Estado y el control sobre los recursos, las políticas de liberalización económica para atraer a los inversores extranjeros y crear el clima propicio para que inviertan su capital en la extracción de recursos naturales, y las fuerzas extranjeras. Sin dejar de reconocer la importancia de los enfoques anteriores para explicar los conflictos de recursos en África, en este trabajo se pretende exponer los conflictos por los recursos como una lucha por el espacio entre las comunidades, mineros artesanales y pequeños y las corporaciones mineras extranjeras a gran escala. Mediante el uso de fuentes secundarias, sostenemos que algunos conflictos de extracción de recursos naturales en África, pueden ser mejor entendidos si nos acercamos a ellos como una lucha por el espacio. Esto sin embargo, no significa que los enfoques actuales se vuelven inútiles. Más bien se complementa con los enfoques actuales.

Palabras clave: minería, conflictos, espacio, Tanzania, África 


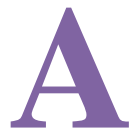

frica's natural resource endowment has for long been one of the driving forces for the violent conflicts in resource rich countries. It appears that there is no single country where natural resources extraction hasn't resulted in conflicts. Good examples of where resource extraction has generated conflicts and civil wars include the Democratic Republic of Congo (DRC), Liberia, Sierra Leone, Nigeria, Sudan, and Angola to mention few (Berman, Couttenier, Rohner, \& Thoenig, 2014).

In Congo DRC, for example, minerals are thought to be the main reason for many years of dictatorship, for the 15 years of political transition, and the seven years of armed national and international conflicts which haveresulted in estimated deaths of 4 million people (Mazalto, 2009, p. 189; Coghlan et al. 2006, cited in Mazalto, 2009, p. 189). In Sudan, a recent mineral conflict between two Arab tribes, theRizeigat and Bani Hussein, over the Jebel Amer gold mine near Kabkabiya in North Darfur region, killed more than 800 people and displaced some 150,000 otherssince January 2013 (Berman, Couttenier, Rohner, \& Thoenig, 2014, p. 1). In Nigeria's Niger Delta, oil extraction has been and continues to be a major reason for the region's instability, insecurity, and violence (Uzodike \& Isike, 2009; Ferguson, 2006).

In Tanzania, despite being regarded as an island of peace, mineral extraction hasn't spared the country from resource based conflicts. Most notable have been conflicts between large scale miners and artisanal and small scale miners on the one hand, and large scale miners and surrounding communities on the other. For example, in May 2011 a conflict between the North Mara people and the police ensued following a group of 1,500 people trespassing the African Barrick's North Mara Gold Mine to 'steal' ore from the mine's stockpiles (Fraser Institute, 2012). Such and other related conflicts occur frequently in the Lake Victoria gold fields largely because of increasing grievances over resources not benefitting communities, dispossession of land for large scale mining, among others (Hall, 2010; Carstens \& Hilson, 2009).

Given the commonality of resource conflicts in Africa, a relatively large body of literature exists on the subject. Many scholars have tended to characterise resource conflicts as something to do with either human characteristics/factors (greed, grievances, etc.) or natural resources 
characteristics (such as specialised skills required to exploit and refine a resource, liquidity, smugglability, etc.). Significant this characterisation may be, it still does not adequately capture the complexity of resource conflicts.

The present paper shifts attention to space as a significant variable in explaining resource conflicts in Africa. It argues that conflicts related to natural resources extraction in Africa are not only a function of human and natural resources characteristics but also a result of the struggle for space between large scale miners and communities and artisanal and small scale miners. To substantiate this argument, the paper draws cases and examples from Tanzania's mining sector. Although not characterised by violent conflicts like those in Nigeria, Congo DRC, Sudan, etc., mineral extraction in Tanzania hasn't been free from conflicts.Indeed, there have been conflicts between large scale and small scale miners on the one hand and large scale miners and the communities surrounding the mines on the other. Moreover, many researches on resource conflicts in Africa have overly focused on those countries such as Nigeria, Congo DRC, Angola, etc. where violent conflicts and civil wars have been reported. As such other resource rich countries haven't been studied adequately. By choosing Tanzania, this paper hopes to address this gap. The paper uses two mineral conflict cases from Tanzania: the Bulyanhulu and North Mara conflicts. The choice of these two cases is based on the fact that they are the most notable conflict cases in the country. They also are representative in that they include three parties to the conflict: large scale miners, artisanal and small scale miners, and mining communities.

Treating resource conflicts as struggle for space is significant in two ways: in the first place, the approach enables us to place significance of space at the centre of resource extraction conflicts; thus shifting focus from overly economic and political discourses. In this sense, the approach is different from the rest in that it recognises that resource conflicts occur not because of the value people attach to them or of their characteristics but because of need to acquire, control, own and maintain/protect space on which resources are found. Access and control over space makes it possible for one to access economic benefits associated with resources without which a resource is rendered useless no matter how valuable it may be. Secondly, it offers a new way of approaching conflict management; that is to say instead 
of devising corporate social responsibility strategies that aim at compensating the communities for their losses, it is important to recognise the importance people/communities attach to space.

The rest of the paper is organised as follows. Section two surveys cases of resource based conflicts across Africa. Building on this, section three examines how resource conflicts in Africa are explained in the literature followed by section four which presents cases and examples from Tanzania to explain how resource conflicts can be associated with struggle for space. Thereafter, a conclusion is provided.

\section{Natural Resources Conflicts in Africa}

Natural resources are an integral part of society and as primary generators of income, industry, and identity in developing countries (USIP, 2007, p. 6). It is point of no doubt that natural resources are an important element in understanding the nature of conflicts in Africa due to their role on such conflicts (Mwanika, 2010, p. 6). It is possibly that conflicts involving natural resources have increased and widened devastating consequences and brought tragedy in terms of stability and peace-building in countries under such tense situation. In Chad, for instance oil is linked to the complexity of the resources, conflicts, and national politics (Humphreys, 2005, p. 509), where the state is responsible for the crisis. Humphreys (2005, p. 511) citing Collier and Hoeffler (2000) argues that conflicts may be understood as an attribute of greed and grievances rooted in political marginalization. Natural resources have played a principal role in defining much of Africa's public arena, in terms of power politics, resource distribution and establishing new electoral regimes in much of continent's administration realm (OSAA, 2010, p. 7; Mwanika, 2010, p. 1). The prevailing conflicts embedded on natural resources have amplified killings and armed conflicts in Africa and this has proven to impede efficiency and performance of the states towards improving citizens' livelihoods. Various natural resources are entrenched in an environment, geographic, geopolitical and interdependent space where actions by one individual or group may generate effects outlying beyond definite national authorities (Mwanika, 2010, p. 2). 
Considering natural resources conflicts in Africa, numerous countries have gone through different phases of chaos ever since these precious resources were discovered. Conflicts have glorified killings of innocent women, men and children for the past four decades in Africa. For example, Silberfein (2004, p. 215) argues that despite the Sierra Leonean economy being diversified, diamonds played a very significant role on civil wars, because diamonds contributed to enrichment of politicians with illicit wealth. Moreover countries such as the Democratic Republic of Congo (DRC), Angola, Sudan, Nigeria, and Liberia, are some examples of countries that are endowed with oil and mineral resources but occupied by social inequality, high incidence of poverty and conflict (Omeje, 2008; Wilson, 2010, p. 1).

Nigeria, like many other oil-producing countries has not been spared from long lasting fighting and pain of violent conflicts attributed to her oil resource management. For example there has been an ongoing violence and uprisings in the Niger Delta where conflicts have involved kidnapping and blowing up of oil installations and killing an estimated 1,000 people between 1999 and 2004 (Oyefusi, 2007, p. 3). In this region, the conflict has escalated from just an ethnic minority protest against the state-multinationals alliance to organised insurgencies in the area (Obi, 2009). These insurgencies involve attacks on state and oil companies by local groups such as Movement for the Emancipation of the Niger Delta (MEND), Nigeria Delta Peoples Volunteer Force (NDPVF), and the Niger Delta Vigilante (NDV), among others (Obi, 2009). In short, natural resources (especially minerals and hydrocarbons) all over Africa have made resource related conflicts appear like a norm to accompany any resource extraction activity. This is irrespective of whether or not a resource rich country has a long history of instability; resource conflicts have happened in almost all resource rich countries, even those like Tanzania, Ghana, etc. which are generally considered peaceful and stable. This is what has made many scholars to delve themselves into researching resource conflicts in Africa in an attempt to try understand them.

\section{Explaining Natural Resources Conflicts in Africa}

While it is generally agreed that there exists a relationship between natural resources exploitation and conflicts in Africa, explaining how and why such 
is the case remains a fertile ground for debate among academics, practitioners and other commentators. Looking at the available literature on natural resources and conflicts in Africa, one realises that there are several strands of arguments.A classical approach is the neo-Malthusian perspective. The principal notion of the perspective is rooted on the idea of the scarcity of resources. Resource scarcity is believed to be one of the triggers of resource conflicts in Africa and elsewhere. A recent study found out that resource scarcity may be a trigger of conflicts while resource abundance positively and significantly impacts on income, therefore reducing the risk of conflicts/war (Brunnschweiler \& Bulte, 2008, p. 17). Thomas Malthus was convinced that the limitedness of resources, especially land imposed decreasing rates of return on all other factors of production and put an absolute scarcity constraint on food production in particular (Neumayer, 2006, p. 4). This perspective further holds that rapid population increase, environmental degradation, resource depletion and unequal access to natural resources exacerbate poverty and income inequality in poor countries (USIP, 2007, p. 8). It is argued that because of the long term deprivation entrenched on unequal access to little resources, those internal disputes are translated into grievances and increase risks to societal conflicts and rebellion (USIP, 2007). The argument is that what causes natural resources conflicts is the deprivation of people and societies of access to and ownership of natural resources on which they depend for their livelihoods (Mildner, Lauster, \& Wodni, 2011). The challenge with this perspective is that modern resource conflicts are too dynamic and complex to be explained by a simplistic resource scarcity argument. As it is argued human beings are capable of transcending limitations set by resource scarcity through innovating new ways to substitute resources or inventing new technologies (Mildner, Lauster \& Wodni, 2011).

Another perspective is resources abundance approach. It is believed that while many perceive resource conflicts is attributed to scarcity, some have equated the problem with "resource curse" (USIP, 2007), linked to practices such as leadership laxity, economic decline that have exacerbated violent conflicts over national revenues. Resource abundance perspective scholars believe that the abundance of resources can provide avenues for using resources to finance rebellion or for looting the resources for personal gains 
(Mildner, Lauster \& Wodni, 2011).Contestation over ownership and control of such resources as diamonds and other minerals is what triggersresource conflicts (USIP, 2007). What brings all this, it is thought, are greed and poverty (Mildner, Lauster \& Wodni, 2011; Collier \& Hoeffler, 2004).

Evidence further suggests that the greed of rebels and desire to capture state for controlling rentsgenerated from revenues cause instability and dissatisfaction and result in endless fights as happened in Sierra Leone, Democratic Republic of Congo (DRC), and Chad (Humphreys, 2005, p. 512). In some cases it has been documented that appropriated revenues from illicit funds have been used to buy illegal arms that support fights to exploit more resources (OSAA, 2010, p. 52). For instance, studies show that the role of foreign governments who provide moral and material support has escalated resources conflicts. United Nations Panel Experts on the Illegal Exploitation of Natural Resources and Other Forms of Wealth in the DRC named Uganda as a country with no diamonds but became a good exporter after occupying areas in DRC through rebels (OSAA, 2010, p. 54).

In recent times, however, the greed/grievance thesis has been redeveloped to include an aspect of feasibility: that natural resources result in conflicts only when it is financially and militarily (materially) feasible to do so (Collier, Hoeffler \& Rohner, 2009, cited in Mildner, Lauster, \& Wodni, 2011, p. 163). In spite of its fame, the traditional greed/grievance approach to resource conflicts has increasingly become questionable given the fact that resource conflicts may have more to do with other factors than with greed and grievances (Atta-Asamoah, 2013; Mildner, Lauster, \& Wodni, 2011). As Humphreys (2005, p. 510) argues, 'the correlation between commodities and conflict does not imply either that rebels are greedy or that they finance their campaigns through the trade in natural resources'. Greed and grievance perspective has also been criticised for assuming all conflicts are a product of greed and grievances (Alidu, 2013).

This is why some scholars have attempted to establish a link between natural resources and conflicts in Africa by looking at the characteristics of natural resources. Mildner, Lauster, \& Wodni (2011) argue that natural resource characteristics play a significant role for the onset, duration and intensity of conflicts. Resource accessibility to potential rebels, location of production, and the value of the resource are very important resource 
characteristics associated with resource conflicts (Mildner, Lauster \& Wodni, 2011). Furthermore, it is posited that it is the presence or lack of these characteristics that fuels a conflict:

\begin{abstract}
a given resource has a higher chance of fuelling conflict when it has characteristics that require less specialised skills to exploit and refine it, has high liquidity, and is highly portable and therefore 'smugglable'. ... in the case of a lack of these characteristics, the role of a natural resource in conflict is a factor of state weakness, where the greed of existing political elites prevents the benefits from trickling down to the entire or a militarised section of the population, very often the host communities to the resource (AttaAsamoah, 2013, pp. 1-2).
\end{abstract}

The idea is that despite the significance of human-centred explanations of resource conflicts in Africa, one cannot adequately understand the complex and dynamic nature of resource conflicts without taking in consideration the characteristics of natural resources (Atta-Asamoah, 2013). A combination of the greed/grievance and natural resource characteristics would thus give a balanced account of resource conflicts in Africa (Atta-Asamoah, 2013). This, again, does not provide a complete account of resource conflicts in Africa because it does not give room for the geopolitical interests and the organisation of space and how these fuel conflicts in Africa.

Lastly, resource conflicts in Africa are also explained by using an externalist approach.The approach sheds light on the relationship between neoliberal reforms and investments from big multinational companies in Africa. The principal concept of the approach is based on the idea of using reforms on domestic policies while maintaining flow of resources in the language of governability (Wittmeyer, 2012, p. 4). Dwelling on the idea of governance the process does not manifest through power of money and integration on state's affairs only; rather they occupy position and influence reforms by setting new regulations in the policy process (Harrison, 2001, p. 670). Such processes have played a role on internal resources conflicts and disputes between investors and citizens. For instance, in Tanzania evidence shows that from 1980s foreign investors have seized a lot of hectares in areas such as Rufiji, Kisarawe and Bagamoyo for biofuels production 
resulting in disputes over land (Hakiardhi, 2009, p. 6). Another aspect of externalist approach concerns the role of dependency on aid from donors. It is estimated that African countries are greatly dependent on aid, whereas over 50\% Uganda's and Tanzania's national budgets are run by aid (Shikwati, 2006, p. 4). In such scenarios, the African leadership has little enticement to listen to their electorate but donors (Shikwati, 2006). For example, literature indicates that in 1998 Africa suffered 11 major aid fuelled conflicts as result governments spent about 15 billion USD on arms and military to build institutions that enhance trust on trade and investment (Wittmeyer, 2012, p. 5; Shikwati, 2006, pp. 4-5). Mirroring from this perspective, it is unsurprisingly to say that undoubtedly neoliberal reforms have contributed a lot on resource conflicts in Africa.

\section{Resource Conflicts as a Struggle for Space: Mining in Tanzania}

Natural resource conflicts in Africa and elsewhere in the world, as seen above, are generally associated with the natural characteristics of resources and the human behavioural factors such as greed and grievances. Although these may in some way be related to spatial issues, current analyses do not link resource conflicts with struggle for space. The present paper takes on this challenge and uses the case of mining in Tanzania to argue that some resource conflicts may better be understood in the context of the struggle for space between the miners and the communities. Arguably,

In order to be able to live and work man has to make use of the space surrounding him, whether this be the countryside or the urban environment. Such use has almost never been without its problems, however, nor is it today in the Third World, certainly not for the poor, who are often thrown back more than other population groups on the immediate utilisation of a piece of land for their daily subsistence. As users of space they are suffering increasingly from competition, to such an extent that in certain regions there is already a direct and open struggle for space, which is often to the detriment of the poor (Kleinpenning, 1982, p. 3).

Space is a concept that is very difficult to define although it is the very basis of human geography (Mazúr \& Urbánek, 1983; Thrift, 2009). 
According to Thrift (2009, p. 105), 'space arises out of the hard and continuous work of building up and maintaining collectives by bringing different things (bodies, animals and plants, manufactured objects, landscapes) into alignment'. Space is thus something that shows how different things and/or organisms are placed against and how they relate to each other. In this paper, we adopt Thrift's (2009) two of the four categorization of space: the block space and place space. Block spacerefers to the process whereby routine pathways of interaction are set up around which boundaries are often drawn, and place space refers to the process whereby spaces are ordered in ways that open up affective and other embodied potentials (Thrift, 2009, p. 105). These two kinds of space are important to this paper because they reflect the complexity of the concept space itself and highlight the fact that space usually goes hand in hand with the need to set boundaries for assigning usage to a particular space which in turn affects society/human beings in different ways. We submit here that designating a particular space for a particular activity (such as mining) may not bode well with pre-existing usages thus providing a fertile ground for conflicts to emerge. Such conflicts emerge in the context of a struggle for acquisition and ownership of space on the one hand, and maintenance and/or protection of space on the other. As this struggle will very much reflect power inequalities, powerful actors (large scale miners) will prevail over less powerful ones (artisanal miners and communities).

It is in this context that mining conflicts in Tanzania and elsewhere in Africa can be understood as a manifestation of the struggle for space acquisition, control and ownership by the miners and the communities. Mining conflicts are generally associated with mining community struggles 'to protect economic and social values of importance to them, to assert the right to refuse a mine, or to advance claims on mining companies for damages' (Coumans, 2011, p. S29). They can also be associated with miners' and government's push to establish/open mine projects in areas occupied by communities without much regard to community needs and rights to space. Any mismatch between the miners and community interests generates a resource extraction conflict.

Given that, it makes sense to treat resource conflicts as struggles for space acquisition, control, ownership, maintenance and/or protection. This is 


\section{Poncian \& Kigodi-Natural Resource Conflicts}

because mining involves a redefinition and/or alteration of space so much that the original spatial organisation is replaced by a new one. This happens in a number of ways and due to a number of reasons. Firstly, mining takes place mostly on land resource space, the same resource that communities use for settlement and livelihood production; so it is impossible to have minerals extracted without redefining that space by displacing and dispossessing people and communities of their land (Kitula, 2006). Secondly, natural resources do not occur in vacuum; they occur in space. This means that without access to and control over space one cannot get access to resources. Thirdly, when mining space is created and mines are established, especially the large scale mines, they are usually gated so much that surrounding communities can no longer have access to the areas. Sometimes, they are not even allowed to come close or trespass through the areas under large investors, the same areas they used to own before they were dispossessed. Fourthly, establishing a large scale mine sometimes involves forceful eviction of long established artisanal and small scale miners to give way for large scale, often foreign, investors to mine the area. This makes artisanal and small scale miners to loose their control and access to a particular space.

Fifthly, large scale mining projects involve connived relationship between miners and the state where the state uses its machineries to protect mining sites at the expense of surrounding communities. This is done in the name of promoting national economic interests (Owugah, 2001), thus leaving communities as 'orphans' in their home countries. Moreover, large scale mining investments come with lots of development promises which make local governments to do everything possible to attract investors and protect them, and the local communities have greater expectations which are rarely fulfilled. Lastly, the discovery of a mineral resource comes with greater expectations both from the government and local communities. Thus, it makes many want to control and own the space on which a resource is found in order to reap benefits for their own development. A combination of unfulfilled promises and loss of space by the communities breeds mining related conflicts. When it happens that access to a mineral resource is restricted or that large scale investors have been given concession over an area, some people would forcefully invade an area to mine. For example, the Obuasi area has reportedly witnessed such conflicts where artisanal and 
small scale miners have continuously been invading the Anglo Gold Ashanti concession for mining thus sparking disputes and violent clashes between the two parties (Okoh, 2014).

It is in these conditions that local communities fight to protect their interest and right to space on the one hand, and miners strike back to make sure that their access and control over investment space is not jeopardized. This brings in a resource extraction conflict between communities, artisanal and small scale miners and large scale miners. The following cases help exemplify this link.

\section{The Bulyanhulu Conflict}

This is a case involving the re-definition of mining space from that occupied and owned by artisanal and small scale miners to that owned by large scale miners. The conflict emerged as a result of forceful eviction of artisanal miners while clearing the Bulyanhulu site for large scale mining investment in 1996. In the process of evicting artisanal and small scale miners, it was reported that Kahama Mining Corporation Limited (KMCL) and government forces allegedly used bulldozers to bury alive over 50 artisanal and small scale minerswho refused to vacate the area they claimed to be legally theirs (Aminzade, 2013; Glynn, 2006; Mining Watch Canada, 2005; Bretton Woods Project, 2002; Nelson, 2002).This stemmed out of the fact that between 30,000 and 400,000 artisanal and small scale miners were working in the area since the 1980s and claimed to be the owners of the area (Mining Watch Canada, 2005). When KMCL acquired exploration rights in the area in the early 1990s and began processes of evicting thousands of artisanal miners, the artisanal and small scale miners were determined to defend their right to and ownership of the Bulyanhulu mining space which was now being threatened by the large scale miners.

Thus, it is not surprising that artisanal and small scale miners decided to go to court to stop eviction but to no avail as the eviction of the 'squatters' continued despite the High court injunction (Mining Watch Canada, 2005).This shows the extent to which the large miners supported by government and able to circumvent judicial processes to their advantage were determined to acquire and own space for large scale mining. It also 


\section{Poncian \& Kigodi-Natural Resource Conflicts}

shows how determined artisanal miners were to defend their right to ownership of space. Although both the government and the investors denied allegations of burying small scale miners alive, the fact that the miners were dubbed as squatters and forcefully evicted signifies the loss of space by the small scale miners and surrounding communities. This conflict clearly depicts a struggle for mining space between large and small scale miners. Small scale miners were using their long experience in the area and judicial procedures to struggle for defending their mining rights and livelihoods by maintaining access to and control over the mining space. Large scale miners, on the other hand, were using their legal exploration rights together with state backed force to evict artisanal and small scale miners so that they could have exclusive access to, control and ownership of the Bulyanhulu mining space. Because artisanal and small scale miners and communities did not have enough resources and authority to counteract the combined power of KMCL and the government, they lost their mining space. However, conflicts and violence have since continued recurring as exemplified by the following case.

\section{Mining Conflicts at North Mara Gold Mine}

The North Mara Gold Mine, opened in 2002 and owned by Acacia (formerly African Barrick), is the most contentious mine in Tanzania characterised by frequent conflicts between the mine and the surrounding communities. Serious human rights issues such as killing of citizens, rape, etc. have continuously been reported in the media. The area now owned by Acacia used to be an artisanal and small scale mining site in the past; which means that artisanal and small scale miners were squeezed out of the area when the land was sold to foreign investors allegedly without full consultation with and consent of the local communities (Oke, 2014; Mlowe \& Olengurumwa, 2011). The dispossession of land, forceful displacement of miners and communities, the gated/enclave nature of the large scale mine, and frustrations of the communities over unfulfilled promises of development combine to make the area frequently violent. It is reported that,

In the beginning of the Barrick takeover, the company was highly resisted by villagers who feared the loss of their land and small 
locally-owned and operated mines. In spite of the strong resistance from the villagers, Barrick managed to even acquire more land for the mining site in 2002. Members of the village state that over the years many people have lost their lives, hundreds remain amputated and others were unreasonably charged with fabricated criminal cases. Villagers interviewed state that from 2004, the company has been taking villagers' lands it requires by force for its mining operations. This is done by simply dumping millions of tons of waste rock and rubble onto village lands without even the pretense of seeking owners' consent or payment of compensation as required by the law (Mlowe \& Olengurumwa, 2011, p. 7).

The conflict between the North Mara mine and the surrounding villages/communities manifests itself mainly in the invasion of the mine by organised groups of villagers to look for gold traces. For example, on $17^{\text {th }}$ January, 2014 more than 2,000 men armed with machetes, stones and hammers raided the Mine in search of waste rock filled with tiny amounts of gold resulting in the injury of one officer and death of one of the 'intruders' (The Citizen, 2014).Similarly, in 2011 a group of 1,500 people trespassed to 'steal' ore from the mine's stockpiles resulting in a confrontation between Tanzanian police and trespassers that left five 'intruders' dead and a number of police officers injured (Fraser Institute, 2012). Similar 'intrusions' happened in July and November 2012, 2009, etc. (The Citizen, 2014; Oke, 2014).

The violence and conflicts in the areas surrounding the North Mara Gold Mine as reflected in frequent intrusion of the mine by the local people is a clear indication of a continued struggle by the local people for space acquisition in an area that is already gated and highly secured. Although the organised groups are called intruders by the investors and the government forces, they are actually people who were forcefully evicted from their traditional land and small scale mining sites to give way for foreign investors. They are a people who used to earn a living from small scale mining in the area when they still had access and control over the area; a people who have lost spatial control and access to the mining area. Instead of regarding them as intruders, trespassers, thieves and the like, these should be regarded as people who continuously struggle for mining space acquisition. 
Recognising the fact that they cannot regain their lost space, the fact that the large scale miners have protection from the government, and the unfulfilled promises of development, surrounding communities resort to 'intrusion' as a way of compensating for their spatial losses. As long as the communities continue feeling that way, violence and conflicts will continue no matter how hard the mining companies may be trying to resolve them. This explains why Acacia (African Barrick) seems to be puzzled on what more needs to be done to co-exist peacefully with communities after trying a number of corporate social responsibility initiatives in the area (NewenhamKahindi, 2011). Similar cases of confrontation between communities and mining investors over rights to space have occurred in the Geita Gold Mine area where it is reported that,

...some 1800 villagers were forciblydisplaced in Mtakuja,
Nyamalembo and Nyamangevillages in Mtakuja Ward, following
the establishmentof the Geita Gold Mine. The displacement
threatenedpeoples' livelihoods and has resulted in
confrontationbetween the local people and staff at the Geita
GoldMine. An influx of foreign mining companies has madeit even
more difficult for locals to secure land.... Asa result, several small-
scale miners and farmers have losttheir mine sites, agricultural and
grazing lands. ...Displacement has already caused conflicts between
thelocal people and the mine operators. There have sincebeen
additional social conflicts between small-scaleminers and the large-
scale mining companies, as the(small-scale) miners have begun to
find that areaspreviously open to prospecting and mining of gold
isnow under the control of a private foreign company (Kitula, 2006,
p. 411).

This and other two cases above show how space is very important in understanding some of the conflicts related to resource extraction. Wherever local people are forcefully evicted from their land or artisanal miners from their mining sites, conflicts have ensued as communities and artisanal miners have fought back trying to regain their control over space. In most cases, communities fight back not because they want to own minerals but because they want to regain access and ownership of their lost land resource, a 
resource they are economically, socially and culturally attached to so much that it is like part of their life.

\section{Conclusion}

Natural resources conflicts in Africa continue to evoke theoretical and empirical debate among scholars and practitioners. A quick look at available literature reveals that the question of natural resource conflicts remains inconclusive especially as far as explaining the linkages and mechanisms between resource extraction and conflicts are concerned. The current literature emphasise on the role of greed and grievances, natural resource characteristics, state weakness, and limited or abundant natural resources as key drivers of resource conflicts in the continent and elsewhere. While recognising the significance of these approaches, this paper has gone beyond and linked resource conflicts with struggles for acquisition, control, access and ownership of space for mining and other livelihood activities. The central argument of the paper is that some natural resource conflicts in Africa can better be understood in the context of community struggles to maintain their access and control over space on the one hand and large mining companies struggles to acquire and maintain ownership over large tracts of land for mining activities. Two cases drawn from Bulyanhulu and North Mara in Tanzania exemplify this linkage.

The argument advanced in this paper does not, however, dispel the importance of other approaches in explaining natural resource conflicts in Africa; it rather builds on what we already know to add on a new a dimension that complements available approaches. As such, the paper has contributed to the growing body of literature and debate on natural resources conflicts in Africa by offering a complimentary approach. As natural resource conflicts are dynamic, complex and varying from case to case, the struggle for space approach cannot explain all resource conflicts in Africa. What it does is to add on the existing debate a new approach that can help explain some of the resource conflicts in Africa. 
288 Poncian \& Kigodi - Natural Resource Conflicts

\section{References}

Alidu, S. M. (2013). Beyond greed and grievance: the missing link in conflict management and peace building in Northern Ghana. Journal of Research in Peace, Gender and Development, 3(6), 90-98. doi: 10.14303/jrpgd.2013.099

Aminzade, R. (2013). Race, Nation, and Citizenship in Post-Colonial Africa: The Case of Tanzania. Cambridge: Cambridge University Press

Atta-Asamoah, A. (2013, January). Besides greed and grievances: Natural Resource Characteristics and Conflicts in Africa. Institute for Security Studies Paper No. 243. Retrieved from http://www.issafrica.org/uploads/Paper243.pdf

Berman, N., Couttenier, M., Rohner, D., \& Thoenig, M. (2014, July 23). This mine is mine!How minerals fuel conflicts in Africa. OxCarre Research Paper 141. Retrieved February 21, 2015, from http://www.oxcarre.ox.ac.uk/files/OxCarreRP2014141.pdf

Bretton Woods Project. (2002, January 17). Tanzanian authorities attempt to silence activists on Bulyanhulu case. Retrieved February 27, 2015, from http://www.brettonwoodsproject.org/2002/01/art-15988/

Brunnschweiler, C. N., \& Bulte, E. H. (2008, January). Natural Resources and Violent Conflict: Resource Abundance, Dependence and the Onset of Civil Wars. Working Paper 08/78. Retrieved February 25, 2015, from http://www.cer.ethz.ch/research/wp_08_78.pdf

Carstens, J., \& Hilson, G. (2009). Mining, Grievance and Conflict in Rural Tanzania. International Development Planning Review, 31(3), 301326. doi: 10.3828/idpr.31.3.5

Collier, P., \& Hoeffler, A. (2000). Greed and Grievance in Civil Wars. Policy Research Paper no. 2355. Washington, D.C.: The World Bank. Collier, P., \& Hoeffler, A. (2004). Greed and Grievance in Civil War. Oxford Economic Papers, 56, 563-595. doi: 10.1093/oep/gpf064

Coumans, C. (2011). Occupying Spaces Created by Conflict: Anthropologists, Development NGOs, Responsible Investment, and Mining: with CA comment by Stuart Kirsch. Current Anthropology, 52(S3), S29-S43. doi: 10.1086/656473 
Ferguson, J. (2006). Global Shadows: Africa in the Neoliberal World Order. Durham: Duke University Press.

Fraser Institute (2012). Does Mining Cause Social Conflict? Retrieved from http://www.miningfacts.org/Communities/Does-mining-cause-socialconflict-/

Glynn, T. (2006, July 5). "There is Death in them thar' Pits". The Dominion. Retrieved from:

http://www.dominionpaper.ca/features/2006/07/05/there_is_d.html

Hakiardhi (2009). The Changing Terrain of Land Use Conflicts in Tanzania and the Future of a Small Producer. Retrieved from Land Rights Research and Resource Institute website http://hakiardhi.org/index.php?searchword=The+Changing+Terrain \& ordering $=\&$ searchphrase $=$ all $\&$ Itemid $=1 \&$ option $=$ com_search

Hall, A. (2010, June). Tanzania's Gold Sector: From Reform and Expansion to Conflict? Foundation for Environmental Security and Sustainability (FESS) Issue Brief. Retrieved from http://www.fessglobal.org/publications/issuebriefs/tanzanias_gold_sector.pdf

Harrison, G. (2001). Post-Conditionality Politics and Administrative Reform: Reflections onthe Cases of Uganda and Tanzania. Development and Change, 32, 657-679. doi: 10.1111/14677660.00221

Humphreys, M. (2005). Natural Resources, Conflicts and Conflict Resolution: Uncovering the Mechanisms. Journal of Conflict Resolution, 49(4), 508-537. doi: 10.1177/0022002705277545

Kitula, A. G. (2006). The environmental and socio-economic impacts of miningon local livelihoods in Tanzania: A case study of Geita District. Journal of Cleaner Production, 14, 405-414.

Kleinpenning, J. M. (1982). competition for Space in Developing Countries: Some Latin American Examples and Suggestions for Further Research. Boletin de Estudios Latinoamericanos y del Caribe, 33, 310 .

Mazalto, M. (2009). Governance, Human Rights and Mining in the Democratic Republic of Congo. In B. Campbell (Ed.), Mining in Africa: Regulation and Development (pp. 187-242). London: Pluto Press. 
Mazúr, E., \& Urbánek, J. (1983). Space in Geography. GeoJournal, 7(2), 139-143. doi: 10.1007/BF00185159

Mildner, S.-A., Lauster, G., \& Wodni, W. (2011). Scarcity and Abundance Revisited: A Literature Review on Natural Resources and Conflict. International Journal of Conflict and Violence, 5(1), 155-172.

Mining Watch Canada (2005, August 9). Backgrounder: Bulyanhulu. Retrieved from Mining Watch website

http://www.miningwatch.ca/backgrounder-bulyanhulu

Mlowe, P., \& Olengurumwa, O. (2011). Killings Around North Mare Gold Mine: The Human Cost of Gold in Tanzania-the Shootings of the Five. Fact Finding Mission Report. Dar es Salaaam: Legal and Human Rights Centre (LHRC).

Mwanika, P. (2010). Natural Resources Conflict: Management Processes and Strategies in Africa. Institute for Security Studies (ISS) Paper 216. Retrieved from http://www.issafrica.org/uploads/216.pdf

Nelson, J. (2002, April 15). The Varsity and the Atkinsonian Special Investigative Report: The Men who Moil for Gold. Retrieved from LabourNet Germany website archiv.labournet.de/internationales/tz/bulyanhulu.pdf

Neumayer, E. (2006). An Empirical Test of a neo-Malthusian theory of Fertility Change. Population and Environment, 27(4), 327-336. doi: 10.1007/s11111-006-0024-3

Newenham-Kahindi, A. M. (2011). A Global Mining Corporation and Local Communities in the Lake Victoria Zone: The Case of Barrick Gold Multinational in Tanzania. Journal of Business Ethics, 99(2), 253-282. doi: 10.1007/s10551-010-0653-4

Obi, C. (2009). Nigeria's Niger Delta: Understanding the Complex Drivers of Violent Oil-related Conflict. Africa Development, 24(2), 103-128. doi: 10.4314/ad.v34i2.57373

Office of the Special Adviser on Africa (OSAA) (2010). Natural Resources and Conflict in Africa: Transforming a Peace Liability into a Peace Asset. Conference Report, United Nations Group Meeting on 17-19 June, Cairo. Retrieved from United Nations website http://www.un.org 
Oke, C. (2014, April 19). The Killing Continues at a Canadian-Owned Mine In Tanzania. from http://www.protestbarrick.net/article.php?id=951

Okoh, G. A. (2014). Grievance and conflict in Ghana's gold mining industry: The case of Obuasi. Futures, 62(Par A), 51-57. doi: 10.1016/j.futures.2013.09.007

Omeje, K. (2008). Extractive Economies and Conflicts in the Global South: Re-Engaging Rentier Theory and Politics. In K. Omeje (Ed.), Extractive Economies and Conflicts in the Global South Multi Regional Perspectives on Rentier Politics (pp. 1-26). Hampshire: Ashgate Publishing Limited.

Owugah, L. (2001). Oil Transnationals, State and Development in The Oil Producing Communities of the Niger Delta. In T. W. Africa (Ed.), Mining, Development and Social Conflicts in Africa (pp. 45-67). Accra: Third World Network Africa.

Oyefusi, A. (2007). Oil Dependence and Civil Conflicts in Nigeria. CSAE Working Paper Series (WPS) 09. Retrieved from http://core.ac.uk/download/pdf/6250435.pdf

Shikwati, J. (2006). The Future of Africa in the World. Inter Regional Economic Network. Retrieved from http://www.irenkenya.com/downloads/articles/The_future_of_Africa. pdf

Silberfein, M. (2004). The Geopolitics of Conflict and Diamonds in Sierra Leone. Retrieved from http://www.artsrn.ualberta.ca/courses/PoliticalScience/474A1/docume nts/SilberfeinGeopoliticsConflictDiamondsSierraLeone.pdf

The Citizen (2014, March 16). The puzzle of Barrick Gold mine versus community conflict. Retrieved from http://www.thecitizen.co.tz/News/The-puzzle-of-Barrick-Gold-mineversus-community-conflict/-/1840340/2246418/-/xi13o2/-/index.html

Thrift, N. (2009). Space: The Fundamental Stuff of Human Geography. In N. J. Clifford, S. L. Holloway, S. P. Rice, \& G. Valentine (Eds.), Key Concepts in Geography, Second Edition (pp. 95-107). London: Sage Publications. 
United States Institute of Peace (USIP) (2007). Natural Resources, Conflict and Conflict Resolution: A study Guide Series on Peace and Conflict. Retrieved from http://www.usip.org/sites/default/files/file/08sg.pdf

Uzodike, U. O., \& Isike, C. (2009). Whose security? Understanding the Niger Delta Crisis as a Clash of two Security Conceptions. African Security Review, 18(3), 103-116. doi: 10.1080/10246029.2009.9627547

Wilson, S. (2010). Diamonds in Sierra Leone, A Resource Curse? The Case of Kono District in Sierra Leone. Retrieved from http://erd.eui.eu/media/wilson.pdf

Wittmeyer, H. (2012). Mozambique's 'Land Grab': Exploring Approaches to Elite Policymaking and Neoliberal Reform. Political Science Student Work, Paper 3. Retrieved from http://digitalcommons.csbsju.edu/cgi/viewcontent.cgi?article=1002\&c ontext=polsci_students

Japhace Poncian is Assistant Lecturer at Mkwawa University College of Education -Tanzania- and PhD Student at University of Newcastle Australia.

Henry Michael Kigodi is Assistant Lecturer at Department of Gender and Woman Studies

Contact Address: FP.O. Box 2513 Mkwawa University College of Education, Iringa, Tanzania. Email: jponcian@muce.ac.tz 